\title{
Georeferencing of adolescents with malocclusion in a capital of Southern Brazil
}

\author{
Georreferenciamento de adolescentes com maloclusão em uma capital do Sul do Brasil \\ Georreferenciación de adolescentes con maloclusión en una capital del Sur de Brasil
}

Received: 07/09/2021 | Reviewed: 07/17/2021 | Accept: 07/19/2021 | Published: 07/26/2021

\author{
Cristiano Zortéa \\ ORCID: https://orcid.org/0000-0003-2545-3180 \\ Universidade Positivo, Brazil \\ E-mail: criistianozortea@gmail.com \\ Prescila Mota de Oliveira Kublistki \\ ORCID: https://orcid.org/0000-0002-3828-2328 \\ Universidade Positivo, Brazil \\ E-mail: prescilamota@hotmail.com \\ Fernanda Mara de Paiva Bertoli \\ ORCID: https://orcid.org/0000-0002-1869-4413 \\ Universidade Positivo, Brazil \\ E-mail: nandabertoli@ hotmail.com \\ Carolina Dea Bruzamolin \\ ORCID: https://orcid.org/0000-0001-8301-5766 \\ Universidade Positivo, Brazil \\ E-mail: carolbruza@gmail.com \\ Flávia Sens Fagundes Tomazinho \\ ORCID: https://orcid.org/0000-0001-5553-6943 \\ Universidade Positivo, Brazil \\ E-mail: flavia.tomazinho@gmail.com \\ João Armando Brancher \\ ORCID: https:/orcid.org/0000-0002-8914-702X \\ Universidade Positivo, Brazil \\ E-mail: brancher.a@gmail.com \\ Simone Tetu Moysés \\ ORCID: https://orcid.org/0000-0003-4861-9980 \\ Private practice, Brazil \\ E-mail: simone.moyses3@gmail.com \\ Carlos Flores-Mir \\ ORCID: https://orcid.org/0000-0002-0887-9385 \\ University of Alberta, Canada \\ E-mail: carlosflores@ualberta.ca \\ Alexandre Moro \\ ORCID: https://orcid.org/0000-0002-3127-1837 \\ Universidade Positivo, Brazil \\ E-mail: alexandremoro@uol.com.br \\ Marilisa Carneiro Leão Gabardo \\ ORCID: https://orcid.org/0000-0001-6832-8158 \\ Universidade Positivo, Brazil \\ E-mail: marilisagabardo@gmail.com
}

\begin{abstract}
The aim of this study was to analyze the prevalence and to georeference the malocclusion traits in adolescents in the city of Curitiba, Paraná, Brazil. Data from a previous cross-sectional study with 538 adolescents aged 10 to 14 years were used. In addition, the following variables were used: gender, Health District (HD) of residence, and presence and malocclusion traits. Fisher's Exact Test, georeferencing, and kernel mapping were used for data evaluation. Malocclusion was observed in 52.4\% of individuals, and the most prevalent occlusal trait was deep bite (22.7\%), followed by excessive overjet $(19.9 \%)$, anterior crowding $(8.0 \%)$, posterior crossbite $(6.5 \%)$, anterior open bite $(4.8 \%)$, and anterior crossbite $(1.7 \%)$. Malocclusion was not associated with gender $(\mathrm{p}=0.389)$ or HD $(\mathrm{p}=0.079)$. However, when stratified by gender, the deep bite prevailed among male. The highest malocclusion trait's prevalence was observed in the HDs of Cajuru, Pinheirinho, Boa Vista, and Cidade Industrial de Curitiba. Despite the absence of significant differences in relation to gender and $\mathrm{HD}$, the prevalence of malocclusion traits in the sample studied was high, especially for deep bite. Additionally, georeferencing proved to be useful for identifying the distribution of malocclusion in Curitiba.
\end{abstract}

Keywords: Malocclusion; Epidemiology; Geographic information system. 


\begin{abstract}
Resumo
O objetivo deste estudo foi analisar a prevalência e georreferenciar os traços de má oclusão em adolescentes da cidade de Curitiba, Paraná, Brasil. Foram utilizados dados de um estudo transversal anterior com 538 adolescentes de 10 a 14 anos. Além disso, foram utilizadas as seguintes variáveis: sexo, Distrito Sanitário (DS) de residência e características de presença e maloclusão. Foram utilizados para a avaliação de dados, o teste exato de Fisher, o georreferenciamento e o mapa de kernel. A má oclusão foi observada em 52,4\% dos indivíduos, e o traço oclusal mais prevalente foi mordida profunda $(22,7 \%)$, seguido por overjet excessivo (19,9\%), apinhamento anterior $(8,0 \%)$, mordida cruzada posterior $(6,5 \%)$, mordida aberta anterior $(4,8 \%)$, e mordida cruzada anterior $(1,7 \%)$. A má oclusão não foi associada ao sexo $(\mathrm{p}=0,389)$ ou ao DS $(\mathrm{p}=0,079)$. Porém, quando estratificada por gênero, a mordida profunda prevaleceu entre os homens. A maior prevalência do traço de má oclusão foi observada nos DS de Cajuru, Pinheirinho, Boa Vista e Cidade Industrial de Curitiba. Apesar da ausência de diferenças significativas em relação ao gênero e DS, a prevalência de traços de má oclusão na amostra estudada foi elevada, principalmente para mordida profunda. Além disso, o georreferenciamento mostrou-se útil para identificar a distribuição das maloclusões em Curitiba.
\end{abstract}

Palavras-chave: Má oclusão; Epidemiologia; Sistema de informação geográfica.

\title{
Resumen
}

El objetivo de este estudio fue analizar la prevalencia y georreferenciar los rasgos de maloclusión en adolescentes de la ciudad de Curitiba, Paraná, Brasil. Se utilizaron datos de un estudio transversal previo con 538 adolescentes de 10 a 14 años. Además, se utilizaron las siguientes variables: sexo, Distrito de Salud (HD) de residencia y rasgos de presencia y maloclusión. La prueba exacta de Fisher, la georreferenciación y el mapeo de kernel se utilizaron para la evaluación de datos. Se observó maloclusión en el 52,4\% de los individuos, y el rasgo oclusal más prevalente fue la mordida profunda $(22,7 \%)$, seguida de un resalte excesivo $(19,9 \%)$, apiñamiento anterior $(8,0 \%)$, mordida cruzada posterior $(6,5 \%)$, mordida abierta anterior $(4,8 \%)$ y mordida cruzada anterior $(1,7 \%)$. La maloclusión no se asoció con el sexo $(p=0,389)$ o HD $(p=0,079)$. Sin embargo, cuando se estratificó por género, la mordedura profunda prevaleció entre los hombres. La mayor prevalencia del rasgo de maloclusión se observó en las HD de Cajuru, Pinheirinho, Boa Vista y Cidade Industrial de Curitiba. A pesar de la ausencia de diferencias significativas en relación al género y HD, la prevalencia de rasgos de maloclusión en la muestra estudiada fue alta, especialmente para mordida profunda. Además, la georreferenciación demostró ser útil para identificar la distribución de maloclusiones en Curitiba.

Palabras clave: Maloclusión; Epidemiología; Sistema de información geográfica.

\section{Introduction}

Malocclusion occurs when the teeth are not properly aligned and/or when there are incorrect relations between the dental arches. This situation can affect the quality of life and psychological well-being of the patients (Alrashed \& Alqerbande, 2021; Oliveira \& Sheiham, 2004). The malocclusion etiological factors include an interaction between environmental, local, systemic, heritability, and genetic factors such as gene polymorphism (Dehesa-Santos, Diaz, \& Iglesias-Linares, 2021; Mew, 2015; Santana, Flores-Mir, Iglesias-Linares, Pithon, \& Marques, 2020; Tomita, Sheiham, Bijella, \& Franco, 2000).

The prevention of malocclusion is considered a potential alternative to treatment, since in many cases, the dental misalignment are due functional conditions. Besides that, in Brazil, the difficulty of access to oral health services results in only the high income groups benefiting from the technical-scientific advances in dentistry (Tomita et al., 2000). Therefore, the importance of the prevention, and the knowing about where the people with malocclusion live, has become even more important.

Malocclusion has been classified as the third most prevalent oral problem, after dental caries and periodontal diseases (World Health Organization, 2003). Some epidemiological studies included the analysis of this condition, such as the latest data of the two Brazilian surveys, in 2003 (Brasil, 2004) and 2010 (Brasil, 2012), have noticed a decrease in cases at 12 years old, from $21.6 \%$ to $20.0 \%$, respectively. Specifically, in the city of Curitiba, capital of the Paraná state, a study focusing only on malocclusion revealed a prevalence of $81.0 \%$ in males and $82.8 \%$ in females in 12 years-old students. In this same city (Calegari, 1996), malocclusion was present in $24.6 \%$ of the sample evaluated at this same age in 2010 (Prefeitura Municipal de Curitiba, 2012). To expand the perspective of the social determinants in the disease development, studies correlated malocclusion with age and socioeconomic status, have been done (Vedovello, Ambrosano, Pereira, Valdrighi, Filho, \& 
Meneghim, 2016). It is also believed that the environment influences, the physical, mental and social balance of individuals, may also be associated with outcomes in oral health (Paula, Cruz, Ramires, Ortega, \& Mialhe, 2017).

As an investigative tool in health, the geographical information system (GIS) allows the location of the place of individual's residence, to be tracked by geographical coordinates. Through spatial visualization, data are discovered and analyzed. This can facilitate the understanding of the etiology in some events, as well as the identification of dental health services, populations that needs treatment, and simulations that support treatment planning (White, Anderson, Bradnock, Gray, \& Jenkins, 2000). This geographical mapping system has already been used in health assessments (Emami, Khiyani, Habra, Chassé, \& Rompré, 2016). For instance, in Canada and Australia, the system was used in research on the distribution of dental professionals (Emami et al., 2016; Kruger, Whyman, \& Tennant, 2012). Other studies also presented the geomapping to assess the risk of dental caries in children (Strömberg, Holmn, Magnusson, \& Twetman, 2012). However, in Brazil there are still few oral health studies that apply some kind of spatial analysis (Carvalho, Moysés, Bueno, Shimakura, \& Moysés, 2010; Moysés, Camilotti, Vetorello, \& Moysés, 2008; Pereira, Pardi, Cortellazzi, Bovi Ambrosano, Vettorazzi, Ferraz, Meneghim, \& Pereira, 2014).

In view of this, the present study sought to analyze the prevalence and to georeference the malocclusion traits in adolescents aged 10 to 14 years-old, from the city of Curitiba, Brazil.

\section{Methodology}

\subsection{Ethical aspects}

This study was based on the previous one described by Bertoli (2016), which was approved by the Institutional Ethics Committee in Research (Register No. 879,404).

\subsection{Study design and data collection}

With a cross-sectional and observational design, the primary study mentioned above, which had 934 participants, aimed to evaluate temporomandibular disorders, malocclusion, and anxiety (Bertoli, 2016). Adolescents of both genders, those aged between 10 to 14 years old, and living in Curitiba, were included. In the year of data collection (2014-2016), the city presented nine Health Districts (HD). Each HD corresponds to a division of the geographic space into regional administrations to improve the organization and distribution of health services (Mendes, 1993). The study sample was probabilistic based on data from the Brazilian Institute of Geography and Statistics - Instituto Brasileiro de Geografia e Estatística in 2010, with 126,077 children regularly enrolled in schools in this city. A representative and randomized sampling of the public and private schools was considered $(\mathrm{n}=19)$, based on TMD prevalence (Bertoli, 2016).

The inclusion criteria were individuals at 10-14 years old, enrolled in public or private schools and whose parents or guardians signed a free and informed consent. The exclusion criteria were individuals complaining about pain of odontogenic origin; orthodontic appliance, occlusal splints or dental prostheses users; severe facial or dental anomalies; caries with extensive coronary destruction; systemic disorders with cognitive or behavioral problems; speech disorders; use of medications such as antidepressants, muscle relaxants, nonsteroidal anti-inflammatory drugs or adolescents who have decided not to take part in the research.

The initial approach involved the application of a questionnaire with the following questions: age (in years), gender (male/female) and HD (Matriz/Cidade Industrial de Curitiba - CIC/Bairro Novo/Cajuru/Boqueirão/Boa Vista/Santa Felicidade/Pinheirinho/Portão).

Five trained researcher with more than five years of experience, performed the examinations, with an intra and interexaminer Kappa coefficient of 0.80 and 0.83 , respectively. For the exams, the same criteria described by Pizolato, Freitas- 
Fernandes and Gavião (2013) were used, which were based on the Angle classification, and the description for anterior and posterior crossbite, open bite, deep bite, excessive overjet as follow. Anterior crossbite was computed when one, two or more anterior maxillary teeth were located lingually in relation to the anterior mandibular teeth; posterior crossbite when two or more posterior maxillary teeth were on the lingual surface of the posterior mandibular teeth; open bite for the negative overbite; deep bite was registered when more than half of the lower anterior teeth were covered by the crowns of the upper anterior teeth; excessive overjet when distance between the palatal face of the upper incisor and the lingual face of the lower incisor was greater than $4 \mathrm{~mm}$. Also, the anterior crowding was measured and noted as positive when it was greater than the corresponding of half the mesiodistal diameter of a lower incisor.

In this study, the Angle classification records were not included. Only the data of the anterior and posterior crossbite, open and deep bite, excessive overjet and anterior crowding were used. For each variable, the possible answers were yes or no. Also, the participant was included in the group "with malocclusion" if at least one positive answer was present.

\subsection{Database creation and statistical analysis}

After base adjustment, with the inclusion only of those who had all the necessary information for the present study, data from 538 participants were analyzed. The descriptive analysis, with absolute and relative frequencies, and Fisher's Exact Test $(\alpha=0.05)$, were performed using the Statistical Package for Social Sciences (IBM® SPSS $®$, Chicago, IL, USA), version 21.0 .

\subsection{Georeferencing}

Regarding georeferencing, the GIS methodology was performed. For that, the Quantum GIS (QGIS) program (version 2.18.3) was used with the geographic databases of Curitiba, such as street maps and HD, which were found on the site of the Institute of Research and Urban Planning of Curitiba - Instituto de Pesquisa e Planejamento Urbano de Curitiba (IPPUC www.ippuc.org.br). The construction of the georeferencing map took place in two stages: in the first, the geographical location of individuals without malocclusion was determined; in the second, the location of those who had malocclusion was considered. For the spatial analysis, maps were developed showing the point intensity of a given phenomenon throughout the study region.

\subsection{Map of kernel}

A heat map was generated in the QGIS program using the kernel density estimator, which allows an analysis of the events using a smoothed spatial estimate, with proportional values to the density of the samples per unit area. It is a statistical method that employs algorithms to calculate density curves, or concentration curves for the specific phenomenon being studied. Basically, for the generation of maps, a mesh of points (grid) is created on it; for each point, the points that are less than or equal to the radius of the circle centered on it are identified. Then, for each point identified inside the circle, the kernel function is calculated at that point and the result is accumulated, thus, the kernel of the grid point is the result of the accumulated sum.In this study was attribute greater weight to the nearest events and lower weight to the furthest ones, with gradual decrease controlled by the bandwidth of a $150 \mathrm{~m}$ radius, a so-called quartic smoothing function.

\section{Results}

A total of 538 adolescents with a mean age of 11.3 years ( $\mathrm{SD}=1.1)$ participated in this study. Of these, $265(49.3 \%)$ were male and 273 were female (50.7\%). 
The prevalence of malocclusion was 52.4\%. The most frequent were deep bite (22.7\%), excessive overjet (19.9\%) and anterior crowding (8.0\%), followed by posterior crossbite $(6.5 \%)$, and anterior open bite $(4.8 \%)$. The least common condition found was anterior crossbite $(1.7 \%)$ (Table 1$)$. Figure 1 shows the absolute and relative frequencies of cases with malocclusion in HDs.

Figure 1 - (A) Distribution and (B) georeferencing of adolescents from 10 to 14 years-old with malocclusion in the HDs of Curitiba, PR, Brazil ( $\mathrm{n}=538)$. Note: Map of the Administrative Division of the municipality.
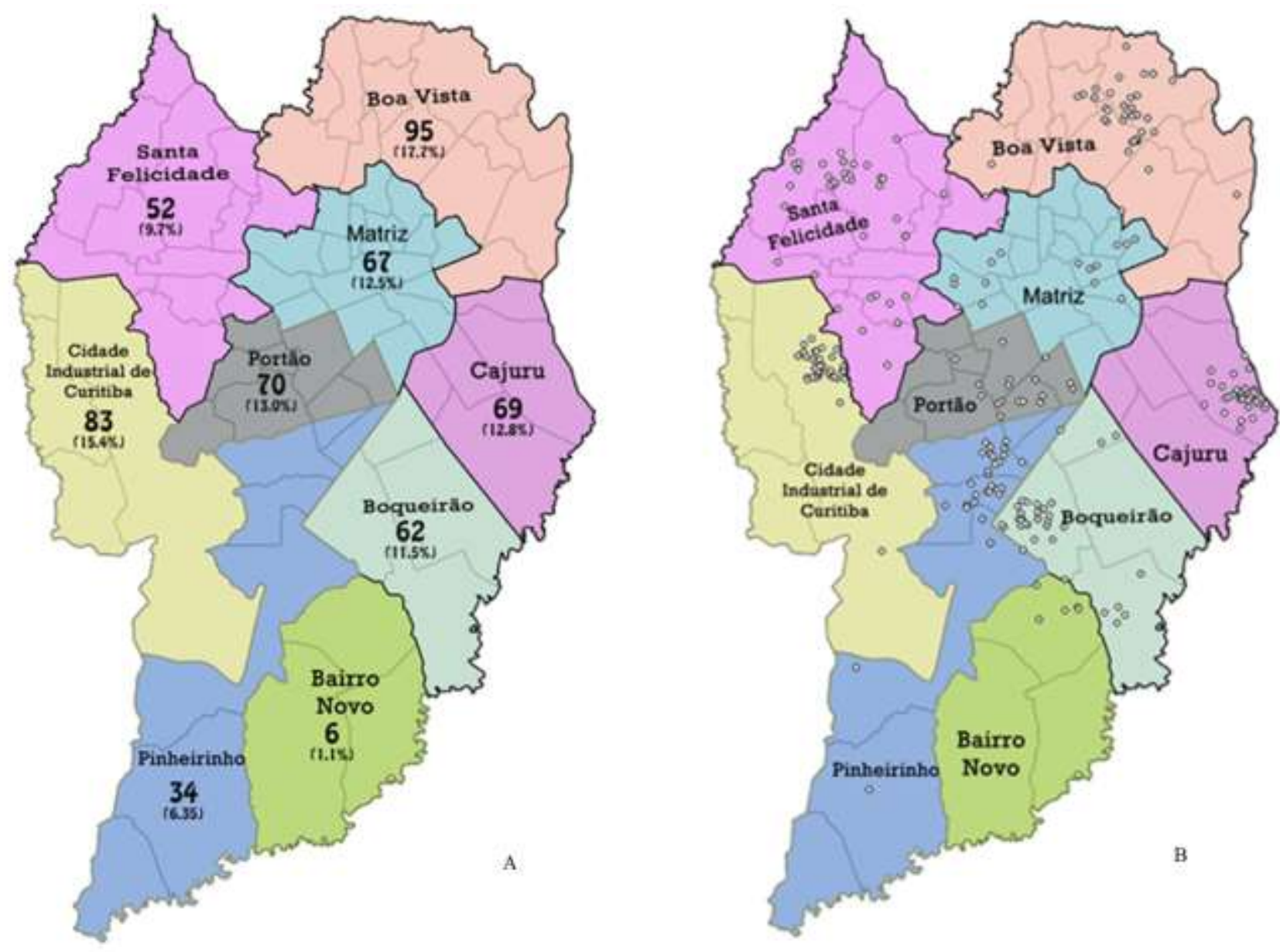

Source Authors. 
Table 1 - Description of clinical variables of adolescents of 10 to 14 years of age from Curitiba, PR, Brazil $(n=538)$.

\begin{tabular}{lc}
\hline Variable & $\mathbf{n}(\boldsymbol{\%})$ \\
\hline Presence of malocclusion & $282(52.4)$ \\
Yes & $256(47.6)$ \\
No & $26(4.8)$ \\
Anterior open bite & $512(95.2)$ \\
Yes & \\
No & $9(1.7)$ \\
Anterior crossbite & $529(98.3)$ \\
Yes & \\
No & $35(6.5)$ \\
Posterior crossbite & $503(93.5)$ \\
Yes & \\
No & $122(22.7)$ \\
Deep bite & $416(77.3)$ \\
Yes & \\
No & \\
Excessive overjet & $107(19.9)$ \\
Yes & $431(80.1)$ \\
No & \\
Anterior crowding & $43(8.0)$ \\
Yes & $495(92.0)$ \\
No & \\
\hline
\end{tabular}

Source: Authors.

No significant association was found in relation to gender, since the malocclusion was presented in $48.9 \%$ of the females and in $51.1 \%$ of the males $(\mathrm{p}=0.389$. However, regarding the prevalence of the types of malocclusion stratified by gender, showed a difference in the deep bite $(\mathrm{p}=0.005)$, with male having this alteration 1.5 times higher than female (Table 2). Also, no statistical difference was found between malocclusion and HD ( $\mathrm{p}=0.079)$.

Table 2 - Prevalence of malocclusion traits according to gender stratification of adolescents of 10 to 14 years of age from Curitiba, PR, Brazil ( $\mathrm{n}=538)$.

\begin{tabular}{lccc}
\hline $\begin{array}{l}\text { Malocclusion trait } \\
\text { (presence) }\end{array}$ & \multicolumn{2}{c}{ Gender } & \\
\cline { 2 - 3 } & $\begin{array}{c}\text { Female } \\
\mathbf{n}(\boldsymbol{\%})\end{array}$ & $\begin{array}{c}\text { Male } \\
\mathbf{n}(\boldsymbol{\%})\end{array}$ & p value* \\
\hline Anterior open bite & $15(57.7)$ & $11(42.3)$ & 0.548 \\
Anterior crossbite & $4(44.4)$ & $5(55.6)$ & 0.749 \\
Posterior crossbite & $23(65.7)$ & $12(34.3)$ & 0.080 \\
Deep bite & $48(39.3)$ & $74(60.7)$ & $\mathbf{0 . 0 0 5}$ \\
Excessive overjet & $60(56.1)$ & $47(43.9)$ & 0.236 \\
Anterior crowding & $19(44.2)$ & $24(55.8)$ & 0.428 \\
\hline
\end{tabular}

* Fisher's Exact Test $(\mathrm{p}<0.05)$. Bold values are statistically significant. Source: Authors.

Figure 2 shows the spatial analysis performed through the kernel map. It was observed that individuals with malocclusion are distributed geographically throughout the city, however, a higher density was noted in specific areas of the following HDs: Cajuru, Pinheirinho, Boa Vista, and CIC. 
Figure 2 - Map of kernel used to refer to areas of higher concentration of adolescents from 10 to 14 years-old with malocclusion. Note: Areas with warm colors (from yellow to purple) represent a higher density of cases of malocclusion. Map of the Administrative Division of the municipality.

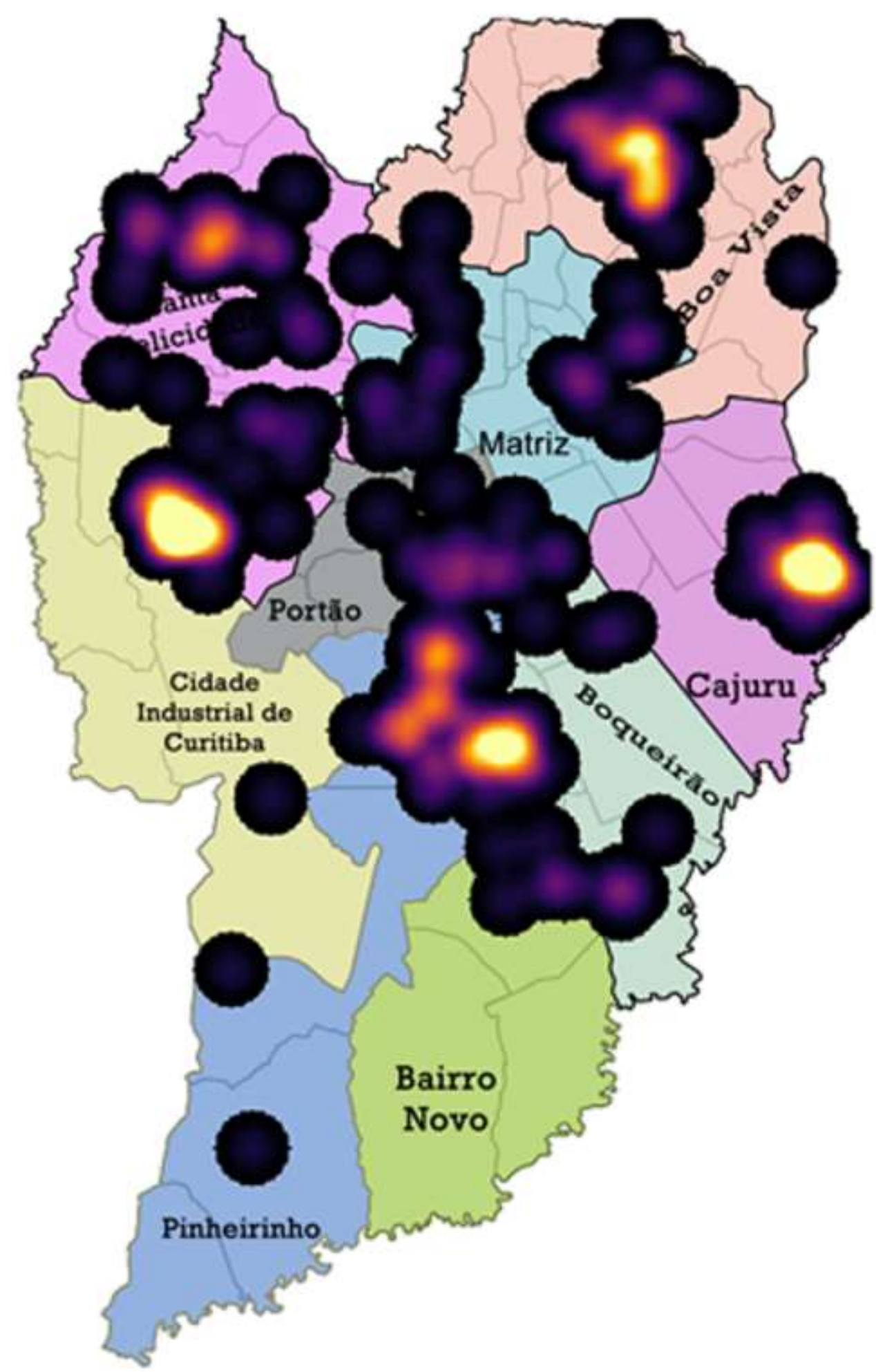

Source: Authors. 


\section{Discussion}

This research aimed to analyze the prevalence and georeference of malocclusion in adolescents, aged 10 to 14 years, in the city of Curitiba. The findings indicated a high prevalence malocclusion (52.4\%) in the sample examined.

First of all, a justification regarding the methodological criteria in the evaluation of malocclusions, adopted here (Pizolato et al., 2013), is opportune. Although Angle's classification is widely used in the literature, the emphasis was given to malocclusions that have mainly environmental factors in their development, such as open bite and cross bite. These data are more relevant in epidemiological surveys for the determination of health intervention planning strategies.

In the epidemiological context, some observations can be made regarding the prevalence of malocclusion. In Brazil, the epidemiological surveys of oral health, performed in 2003 (Brasil, 2004) and in 2010 (Brasil, 2012), revealed that the prevalence of malocclusion at 12 years of age were, respectively, $21.6 \%$ and $20.0 \%$, while very severe or disabling malocclusion condition decreased significantly, from 20.8\% (Brasil, 2004) to 6.5\% (Brasil, 2012). In Curitiba, in 1996, the prevalence at that time was about $80.0 \%$ (Calegari, 1996), and an expressive reduction is observed when the data from 2010 for this same age, showed a value of $24.6 \%$ (Prefeitura Municipal de Curitiba, 2012). This local value is close to the national data of $20.0 \%$ (Brasil, 2012), but superior to the southern region value of 17.0\% (Brasil, 2012).

Also, comparisons with other studies can be made, corroborating the high prevalence found in this research. For example, a study conducted with Brazilian adolescents showed a prevalence of malocclusion of 62.0\% (Marques, Barbosa, Ramos-Jorge, Pordeus, \& Paiva, 2005). Contrarily, some authors identified a better panorama, with 69.6\% (Silveira, Freire, Nepomuceno, Martins, \& Marcopito, 2016) and 68.7\% (Martins, Bittencourt, Bendo, Vale, \& Paiva, 2019) of the samples without occlusal alterations.

In relation to the type of malocclusion, a recent study with 1612 adolescents aged between 11 and 14 years-old, showed that anterior crowding was the most prevalent malocclusion (51.9\%), followed by anterior open bite (7.6\%) (Martins et al., 2019). The high prevalence of anterior crowding was identified in 40.3\% of 16,833 Brazilian adolescents (Freitas, Souza, Mendes, Pordeus, Jones, \& Martins, 2015). In the present study, the most prevalent alteration was deep bite (22.7\%), and the anterior crowding did not exceed $8.0 \%$. As for anterior crowding, the prevalence could be less than that related by other authors because the sample evaluated was in mixed and early permanent dentition. Therefore, some differences can be found between these groups, which could be a limitation in this study.

An epidemiological study, performed in Curitiba, with individuals at 12 years-old, revealed a prevalence of malocclusion of $81.0 \%$ in males and $82.8 \%$ in females (Prefeitura Municipal de Curitiba, 2012). In the present study this same balance was noted, however with lower values for the genders of $51.1 \%$ and $48.9 \%$, respectively.

The findings also did not indicate a significant association between malocclusion, gender and residence (HD) of the individuals. In the adopted territorial division, some neighborhoods are located in HD with better social and economic conditions. For example, it could be hypothesized that residents of more central regions would have some difference from those living in the suburbs, a fact not confirmed in this research.

Many studies have tried to establish associations between social determinants and oral conditions, including malocclusion. However, the results still do not provide conclusive answers. It is important to consider that the territory or residence can influence the social process (Bastos \& Duquia, 2007; Moreira, Nico, \& Tomita, 2007), which may negatively impact the oral health status of their residents (Paula et al., 2017).

The georeferencing of an attribute allows the creation of a map of the territory and a geographical reference of the inhabitants, which favors the understanding of the distribution of health inequities, thus supporting the planning of resource allocation (Frazão \& Narvai, 2006). Specifically, in the dental area, international studies have proposed geomapping with dental professionals (Emamiet al., 2016; Kruger et al., 2012) and the risk of dental caries in children (Strömberg et al., 2012). 
The results of this kind of studies determined the availability of dental care services (Kruger et al., 2012), and their accessibility. It also can determine the presence of adequate infrastructures, coupled with the minimum conditions of the place of residence, such as basic sanitation, security, electricity and all other factors that provide comfort to individuals (Moreira et al., 2007).

Another factor that could be reflected the social economic condition was the school type, although, it was not possible to do this correlation due to a large number of public schools participating in this study. The examination included participants in both private and public schools. However, when the sample calculation in the primary study was performed, the percentage of individuals in private schools was less (23.6\%) than in public ones $(76.4 \%)$ because Curitiba has more public than private schools. Another point worth emphasizing is that not all of private schools had agreed to participate, which could be another limitation of the present study.

The effect of the place of residence in relation to outcomes such as caries, periodontal disease and dental trauma was identified by some authors (Cavalho et al., 2010; de Paiva, Guimarães, Varajão, Marques, Silvestrini, Zarzar, Silva, \& Paiva, 2021; Moysés et al., 2008; Pereira et al., 2014). For instance, Pereira et al. (2014) verified the lack of association between caries and the place of residence of schoolchildren in Piracicaba, São Paulo.

To analyze the data produced by this study and its limitations, it is necessary to consider that the transverse design, which does not allow to establish a causal inference, since the causes and effects are collected at the same moment. Thus, it is impossible to establish a temporal nexus, nor to fully explain the roles of the independent variables in the problem (Bastos \& Duquia, 2007).

Comparative analyses of the malocclusion prevalence and its distribution are not always possible due to the amount of the aspects considered for the evaluation of occlusal conditions in each study. Most cross-sectional studies performed do not show uniformity in the criteria used, as well as in the indices used for occlusal registration, in diverse dentition and age samples (Frazão \& Narvai, 2006).

According to this study, the presence of malocclusion was not associated with variables such as gender and HD of residence, even with the social and economic development differences in these localities. In this sense, the results seem to support other national studies that point out the absence of an association between socioeconomic conditions and malocclusion (Frazão \& Narvai, 2006; Peres, Barros, Peres, Araújo, Menezes, Hallal, \& Victora, 2010; Tomita et al., 2000). However, the higher distribution density of malocclusion in specific regions of the city can show more vulnerable groups, and reinforce the need for a deeper analysis of the socio-environmental conditions that may increase the occurrence of dental problems.

The most frequent malocclusion observed in this research was the deep bite, followed by excessive overjet and anterior crowding. These problems involve an esthetic commitment and can affect an individual's quality of life, especially in terms of personal interrelationships and social life (Vedovello et al., 2016). Similar results were found in previous study on malocclusion in the Brazilian population (Peres et al., 2010).

In relation to gender, there was no statistically significant difference between the adolescents evaluated, corroborating other similar national studies (Frazão \& Narvai, 2006; Prefeitura Municipal de Curitiba, 2012).

As already reported by other authors, actions based on epidemiological data that include the analysis of spatial distribution through georeferencing are essential and elucidate the relationship between the environment and health. This is useful for the application of resources wherever necessary in order to reduce inequities, as well as for the planning and implementation of oral health promotion strategies (Moreira et al., 2007; Moysés et al., 2008; Pereira et al., 2014).

In this sense, the tools used in performing spatial analyses may contribute to the implementation of better health systems, where service delivery can be planned based on priority criteria. 


\section{Conclusion}

Malocclusion is highly prevalent in adolescents who lived in Curitiba, especially the deep bite. Although it is not associated with gender and region of residence of the individuals, a greater number of cases were observed in specific regions of the city. Therefore, the georeferencing can be a useful tool to identify the spatial distribution of malocclusion and plan better dental health strategies to treat and prevent this dental problem.

\section{References}

Alrashed, M., \& Alqerban, A. (2021). The relationship between malocclusion and oral health-related quality of life among adolescents: a systematic literature review and meta-analysis. European Journal of Orthodontics, 43(2), 173-183. http://doi.org/10.1093/ejo/cjaa051.

Bastos, J. L. D.; Duquia, R. P. (2008). One of the most used epidemiological designs: cross-sectional study. Scientia Medica, 17(4), 229-232.

Bertoli, F. M. P. (2016). Prevalência e fatores associados às disfunções temporomandibulares em escolares de Curitiba. Tese (Doutorado em Odontologia), Universidade Positivo, Curitiba, Paraná, Brasil.

Brasil. Ministério da Saúde. Coordenação Nacional de Saúde Bucal. (2004). Projeto SB Brasil 2003: Condições de saúde bucal da população brasileira 20022003: Resultados Principais. Brasília: Ministério da Saúde. http://bvsms.saude.gov.br/bvs/publicacoes/condicoes_saude_bucal.pdf.

Brasil. Ministério da Saúde. Secretaria de Atenção à Saúde. Secretaria de Vigilância em Saúde. (2012). SB Brasil 2010. Pesquisa Nacional de Saúde Bucal: Resultados Principais. Brasília: Ministério da Saúde http://bvsms.saude.gov.br/bvs/publicacoes/pesquisa_nacional_saude_bucal.pdf.

Calegari, M. A. Estudo da oclusão dentária em escolares da faixa etária de 12 anos da cidade de Curitiba. Revista SPRO, 1, 52-66.

Carvalho, M. L., Moysés, S. J, Bueno, R. E., Shimakura, S., \& Moysés, S. T (2010). A geographical population analysis of dental trauma in school-children aged 12 and 15 in the city of Curitiba-Brazil. BMC Health Services Research, 10, 203. http://doi.org/10.1186/1472-6963-10-203.

Dehesa-Santos, A., Iber-Diaz, P., \& Iglesias-Linares, A. (2021). Genetic factors contributing to skeletal class III malocclusion: a systematic review and metaanalysis. Clinical Oral Investigations, 25(4), 1587-1612. http://doi.org/10.1007/s00784-020-03731-5.

de Oliveira, C. M., \& Sheiham, A. (2001). Orthodontic treatment and its impact on oral health-related quality of life in Brazilian adolescents. Journal of Orthodontics, 31(1), 20-77, discussion 15. http://doi.org/10.1179/146531204225011364.

de Paiva, H. N., Guimarães, M. O., Varajão, G. F. D. C., Marques, L. S., Silvestrini, R. A., Zarzar, P. M., Silva, C. J. P., \& Paiva, P. C. P. (2021). Spatial density of adolescents aged 14 years old, victims of dental: A longitudinal study. Dental Traumatology, 37(2), 282-293. http://doi.org/10.1111/edt.12617.

Emami, E., Khiyani, M. F., Habra, C. P., Chassé, V., \& Rompré, P. H. (2016). Mapping the Quebec dental workforce: ranking rural oral health disparities. Rural Remote Health, 16(1), 3630.

Frazão, P., \& Narvai, P. C. (2006). Socio-environmental factors associated with dental occlusion in adolescents. American Journal of Orthodontics and Dentofacial Orthopedics, 129(6), 809-816. http://doi.org/10.1016/j.ajodo.2004.10.016.

Freitas, C. V., Souza, J. G., Mendes, D. C., Pordeus, I. A., Jones, K. M., \& Martins, A. M. (2015). Need for orthodontic treatment among Brazilian adolescents: evaluation based on public health. Revista Paulista de Pediatria, 33(2), 204-210. http://doi.org/10.1016/j.rpped.2014.04.006.

Instituto Brasileiro de Geografia e Estatística (2010). Perfil dos Municípios Brasileiros 2010. http://www.ibge.gov.br.

Kruger, E., Whyman, R., \& Tennant, M. (2012). High-acuity GIS mapping of private practice dental services in New Zealand: does service match need? International Dental Journal, 62(2), 95-99. http://doi.org/10.1111/j.1875-595X.2011.00096.x

Marques, L. S., Barbosa, C. C., Ramos-Jorge, M. L., Pordeus, I. A., \& Paiva. S. M. (2005). Malocclusion prevalence and orthodontic treatment need in 10-14year-old schoolchildren in Belo Horizonte, Minas Gerais State, Brazil: a psychosocial focus. Cadernos de Saúde Pública, 21(4), 1099-1106. https://doi.org/10.1590/S0102-311X2005000400012

Martins, L. P., Bittencourt, J. M., Bendo, C. B., Vale, M. P., \& Paiva, S. M. (2019). Malocclusion and social vulnerability: a representative study with adolescents from Belo Horizonte, Brazil. Ciência \& Saúde Coletiva, 24(2), 393-400. http://doi.org/10.1590/1413-81232018242.33082016.

Mendes, E. V. (1993). Distritos Sanitários: Processo social de mudanças nas práticas sanitárias para Sistema Único de Saúde. São Paulo: Editora Hucitec. Mew, M. (2015). Orthodontics: causes of malocclusion. British Dental Journal, 218(6), 319. http://doi.org/10.1038/sj.bdj.2015.203.

Moreira, R. S., Nico, L. S., \& Tomita, N. E. (2007). The relation between space and collective oral health: for a georeferenced epidemiology. Ciência \& Saúde Coletiva, 12(1), 275-284, 2007. http://doi.org/10.1590/s1413-81232007000100031.

Moysés, S. T., Camilotti, A. G., Vetorello, M., \& Moysés, S. J. (2008). Spatial analysis of dental trauma in 12-year-old schoolchildren in Curitiba, Brazil. Dental Traumatology, 24(4), 449-453. http://doi.org/10.1111/j.1600-9657.2008.00617.x.

Paula, J. S., Cruz, J. N. D., Ramires, T. G., Ortega, E. M. M., \& Mialhe, F. L. (2017). Longitudinal impact of clinical and socioenvironmental variables on oral health-related quality of life in adolescents. Brazilian Oral Research, 31, e70. http://doi.org/10.1590/1807-3107BOR-2017.vol31.0070. 
Pereira, S. M., Pardi, V., Cortellazzi, K. L., Bovi Ambrosano, G. M., Vettorazzi, C. A., Ferraz, S. F. B., Meneghim, M. C., \& Pereira, A. C. (2014). Geographic information system and multilevel analysis: gingival status among 12-year-old schoolchildren in São Paulo, Brazil. Revista Panamericana de Salud Publica, 35(2), 136-143.

Peres, M. A., Barros, A. J., Peres, K. G., Araújo, C. L., Menezes, A. M., Hallal, P. C., \& Victora, C. G. (2010). Oral health follow-up studies in the 1993 Pelotas (Brazil) birth cohort study: methodology and principal results. Cadernos de Saúde Pública, 26(10), 1990-1999. http://doi.org/10.1590/s0102$311 \times 2010001000016$

Pizolato, R. A., Freitas-Fernandes, F. S., \& Gavião, M. B. (2013). Anxiety/depression and orofacial myofacial disorders as factors associated with TMD in children. Brazilian Oral Research, 27(2), 156-162. https://doi.org/10.1590/S1806-83242013000100021

Prefeitura Municipal de Curitiba. Secretaria Municipal de Saúde. Centro de Epidemiologia. (2012). SB Brasil 2010 - Perfil de Saúde Bucal de Curitiba. Curitiba: Secretaria Municipal de Saúde.

Santana, L. G., Flores-Mir, C., Iglesias-Linares, A., Pithon, M. M., \& Marques, L. S. (2020). Influence of heritability on occlusal traits: a systematic review of studies in twins. Progress in Orthodontics, 21(1), 29. https://doi.org/10.1186/s40510-020-00330-8.

Silveira, M. F., Freire, R. S., Nepomuceno, M. O., Martins, A. M., \& Marcopito, L. F. (2016). Severity of malocclusion in adolescents: populational-based study in the north of Minas Gerais, Brazil. Revista de Saúde Pública, 50, 11. http://doi.org/10.1590/S1518-8787.2016050005861.

Strömberg, U., Holmn, A., Magnusson, K., \& Twetman, S. (2012). Geo-mapping of time trends in childhood caries risk - a method for assessment of preventive care. BMC Oral Health, 12, 9. http://doi.org/10.1186/1472-6831-12-9.

Tomita, N. E., Sheiham, A., Bijella, V. T., \& Franco, L. J. (2000). The relationship between socioeconomic determinants and oral habits as risk factors for malocclusion in preschool children. Pesquisa Odontológica Brasileira, 14(2), 169-175, 2000. https://doi.org/10.1590/S1517-74912000000200013

Vedovello, S. A., Ambrosano, G. M., Pereira, A. C., Valdrighi, H. C., Filho, M. V., \& Meneghim, M. C. (2016). Association between malocclusion and the contextual factors of quality of life and socioeconomic status. American Journal of Orthodontics and Dentofacial Orthopedics, 150(1), 58-63. https://doi.org/10.1016/j.ajodo.2015.12.022.

White, D. A., Anderson, R. J., Bradnock, G., Gray, M. M., \& Jenkins, P. (2000). The use of a geographical information system in investigating dental services. Community Dental Health, 17(2), 79-84.

World Health Organization. (2003). The world oral health report 2003: continuous improvement of oral health in the 21 st century-the approach of the WHO Global Oral Health Programme. http://www.who.int/oral_health/media/en/orh_report03_en.pdf. 